\title{
TRANSFORMASI BENTUK GEOMETRIS
}

Oleh: Ridwan Lutfi

Institusi: Institut Seni Indonesia Yogyakarta

\begin{abstract}
Geometric Transformation are obtained from triangular symbol/ icon of lamp in an electricity installation diagram, which designed prior to assembly/ installation of electricity in a building/ location. These geometric (symbols) transformation when transformed onto artworks, will bring diverse possibility of new formation. The purpose of this geometric transformation (from the triangular symbols in electricity) is to explore how artistic the new triangular shape in context of artworks. The triangular shape took as the basic of exploration and experiment in this printmaking artworks, enhanced with light and motion.

Keywords: Transformation, Geometrical shape, Light and motion, Electricity installation.
\end{abstract}




\section{PENDAHULUAN}

\section{A. Latar Belakang}

Pengalaman masa lalu yang sangat berpengaruh pada karya seni penulis dimulai pada masa saat duduk di bangku SMK Teknik Pemanfaatan Tenaga Listrik. Di sini penulis mempelajari hal-hal yang berkaitan dengan listrik, meliputi energi listrik dan instalasi listrik.

"Energi listrik adalah energi akhir yang dibutuhkan bagi peralatan listrik/energi yang tersimpan dalam arus listrik untuk menggerakkan motor, lampu penerangan, pemanas, pendingin ataupun untuk menggerakkan kembali suatu peralatan mekanik dan mengubahnya ke bentuk energi lain." (marsudi Djiteng; 2011, hal. 5)

Dalam proses pemanfaatan tenaga listrik tidak lepas dengan jaringan instalasi listrik. Instalasi berasal dari kata Installation yang berarti memasang, dalam PUIL (Persyaratan Umum Instalasi Listrik) disebutkan: "instalasi listrik ialah jaringan perlengkapan yang digunakan untuk membangkitkan, memakai, mengubah, mengatur, mengalihkan, dan mengumpulkan dari tenaga listrik." (Zuhal; 1995, hal. 6)

Sebelum melakukan pemasangan diperlukan rancangan gambar denah ruangan/bangunan yang akan dipasang instalasi dengan menggunakan simbolsimbol di dalamnya. Simbol digunakan untuk menentukan tata letak komponen listrik yang akan dipasang dalam ruangan/bangunan, seperti; titik lampu, saklar, stop kontak dan panel hubung pembagi. Proses transformasi bentuk dari rancangan gambar ke bentuk pemasangan/perakitan diperlukan proses panjang dan ketelitian agar setiap komponen dapat berkerja sesuai dengan mestinya. Proses transformasi bentuk dari rancangan gambar ke-proses perakitan yang menarik bagi penulis untuk menyelami lebih jauh tentang transformasi bentuk geometris instalasi listrik.

Simbol pada rancangan instalasi listrik mengadopsi bentuk geometris, bentuk yang secara umum mempunyai kontur tegas dan terukur. Pengukur eksternal sama secara matematis dalam berbagai arah disebut dengan bentuk geometris. Berawal dari kecintaan dengan bentuk-bentuk geometris, penulis mencoba menginterpretasikan kembali karya-karya yang pernah penulis ciptakan selama mempelajari seni grafis. Bentuk yang terdapat pada rancangan gambar instalasi listrik memiliki karakteristik bentuk yang khas. Ketika garis saling terhubung satu 
sama lain sehingga memunculkan bentuk-bentuk yang membuat penulis sangat terkesan.

Berlatar belakang masa lalu tersebut, penulis mencoba melihat kembali dan mentransformasikan bentuk geometris yang terdapat pada rangkaian instalasi listrik ke dalam karya seni grafis dengan menambahkan unsur cahaya dan gerak pada nantinya. Dalam proses berkarya (selama mempelajari seni grafis) penulis menggunakan bentuk-bentuk geometris sebagai bentuk dalam bahasa ungkapan pemikiran dan gagasan selama studi.

\section{B. Rumusan Penciptaan}

Secara garis besar penciptaan karya seni penulis berasal dari ide tentang transformasi bentuk geometris, sehingga menimbulkan tiga pertanyaan yang berkaitan dengan masalah penciptaan, yaitu:

1. Transformasi bentuk geometris seperti apa yang akan dihadirkan?

2. Bagaimana transformasi bentuk geometris terjadi ke dalam karya seni grafis?

3. Melalui tehnik apa transformasi bentuk geometris disajikan dalam seni grafis?

\section{Tujuan Penciptaan}

Karya seni yang penulis ciptakan memiliki tujuan dan manfaat bagi diri sendiri maupun masyarakat umum, antara lain:

- Tujuan penciptaan karya:

1. Menciptakan karya seni yang bersifat geometris sebagai media ekspresi, eksplorasi dan pemahaman serta pengetahuan tentang bentuk geometris.

2. Menghasilkan karya seni yang mengeskplorasi bentuk dan makna baru dari transformasi bentuk itu sendiri melalui sudut pandang penulis.

\section{Teori dan Metode}

\section{Teori}

"Sebuah kontraksi dan interaksi antara objek lingkungan dimana manusia ada dengan lingkungannya. Di dalam sebuah kontraksi dan interaksi itu kemudian dilanjutkan dengan proses berpikir, meliputi: memori, stimuli (rangsangan), sensasi, persepsi dan imajinasi. Dan, kebanyakan orang mengatakan bahwa ide ini identik dengan cara 
pandang untuk atau mencapai kebaharuan, disertai dengan nilai guna yang efektif dan efisien untuk orang lain menikmatinya: meskipun untuk produk seni ini agak sedikit berbeda, karena apresiasinya tidak kebanyakan orang pahami." (John W. Santrock; 2010)

Begitu juga dengan pengalaman pribadi penulis, bahwa lingkungan telah mempengaruhi proses berkarya penulis pada saat ini. Pengalaman ketika duduk di bangku SMK Bhakti Praja Jepara menempuh studi Teknik Pemanfaatan Tenaga Listrik. Penulis terkesan dengan simbol rangkaian yang terdapat didalamnya. Melalui pengalaman tersebut, penulis menghadirkan simbol dalam rangkaian instalasi listrik dengan menggabungkannya dengan unsur rupa dan bereskperimental menggunakan unsur gerak dan cahaya. Pengalaman merupakan suatu kesatuan, keutuhan, yang terdiri atas rentetan bagian-bagian pengalaman yang terus mengalir. (Jacob Sumardjo; 2000, hal.161)

\section{Simbol Pada Rangkaian Listrik}

Instalasi listrik adalah peralatan rangkaian listrik yang dirangkai dengan menghubungkan komponen satu dengan yang lain dalam ruangan tertentu untuk tujuan tertentu. Di dalam skema rangkaian instalasi listrik terdapat berbagai macam simbol yang digunakan. Simbol dalam instalasi listrik sebagai tanda penempatan komponen yang akan dipasang. Seperti; lampu, saklar, stop kontak dan panel hubung pembagai (PHB) dalam ruangan/bangunan (gedung).

Pemasangan instalasi listrik dilakukan dengan cara membuat gambar rancangan terlebih dahulu berdasarkan denah bangunan. Gambar adalah bahasa teknik yang diwujudkan dalam kesepakatan simbol. Gambar ini dapat berupa gambar sketsa, gambar perspektif, gambar Proyeksi, gambar denah serta gambar situasi. Gambar denah ruangan/bangunan (gedung) yang akan dipasang instalasi listrik, digambar dengan menggunakan berbagai macam simbol yang berlaku di dalam instalasi listrik menurut PUIL (Persyaratan Umum Instalasi Listrik).

Contoh-contoh berbagai macam simbol yang digunakan dalam rangkaian instalasi listrik: 


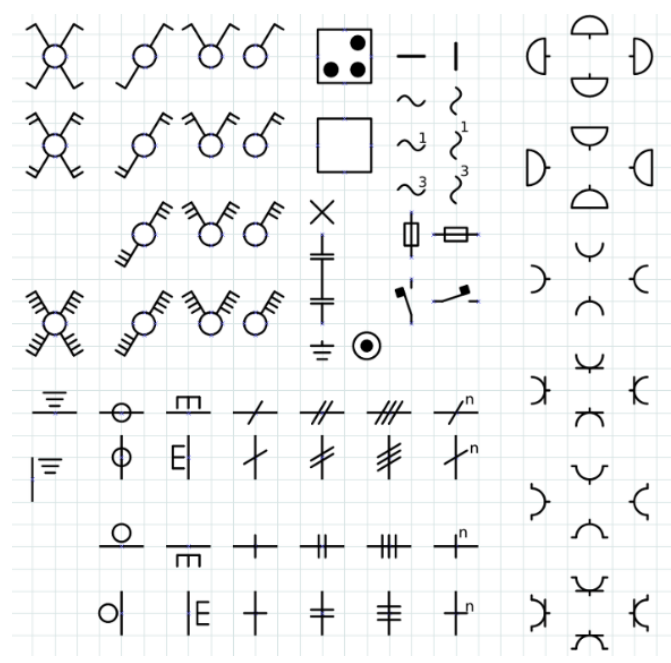

Gambar 1. Berbagai macam simbol rangkaian instalasi listrik.

(Dokumentasi: Ridwan Lutfi)

Berikut ini contoh gambar yang dikerjakan dalam tahap perancangan suatu proses pemasangan instalasi listrik penerangan dan tenaga yang baku menurut PUIL (Persyaratan Umum Instalasi Listrik).
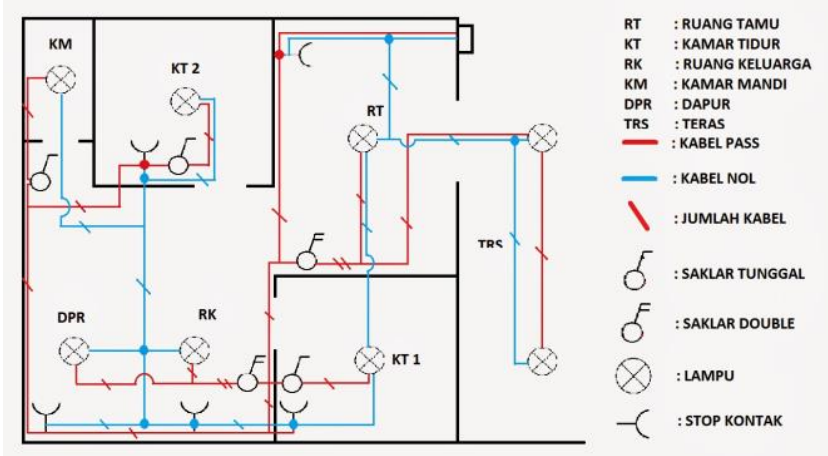

Gambar 2. Diagram instalasi listrik pada rumah tangga satu fasa.

(Dokumentasi: Ridwan Lutfi)

Berbagai macam bentuk simbol pada rangkaian listrik, digunakan untuk menentukan tata letak komponen listrik dalam suatu ruangan/bangunan, seperti: titik lampu, saklar, stop kontak dan panel hubung pembagi yang nantinya akan penulis aplikasikan untuk karya tugas akhir.

Berikut adalah penjabaran beberapa simbol yang terdapat dalam instalasi listrik: 
- Simbol saklar tunggal.

Saklar dengan satu tombol yang fungsinya untuk menghidupkan satu buah fiting lampu, disebut tunggal karena hanya menjalankan dan memutuskan arus untuk satu keperluan.

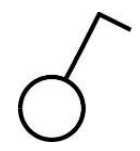

\section{Gambar 3. Simbol saklar tunggal}

(Dokumentasi: Ridwan Lutfi)

- Simbol saklar ganda.

Saklar ganda digunakan sebagai pemutus maupun penghubung arus listrik yang menghidupkan dua fiting lampu dalam satu kotak saklar.

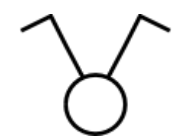

Gambar 4. Simbol saklar ganda.

(Dokumentasi: Ridwan Lutfi)

- Simbol saklar tunggal dalam diagram pengawatan.

Saklar tunggal digunakan sebagai pemutus maupun penghubung arus listrik yang untuk satu lampu.

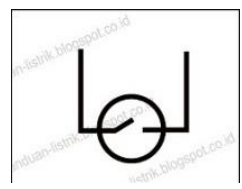

Gambar 5. Simbol saklar tunggal dalam diagram pengawatan.

(Dokumentasi: Ridwan Lutfi)

- Simbol lampu yang terdapat dalam diagram garis tunggal.

Simbol lampu digunakan sebagai penempatan titik lampu yang terdapat pada suatu ruangan/ bangunan.

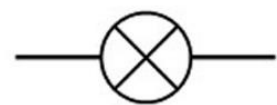

Gambar 6. Simbol lampu yang terdapat pada diagram garis tunggal.

(Dokumentasi: Ridwan Lutfi) 
- Simbol stop kontak.

Stopkontak digunakan untuk menyambungkan arus listrik yang akan digunakan pada alat-alat elektronik maupun motor listrik dengan aman.

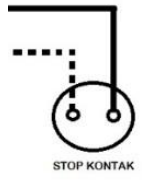

Gambar 7. Simbol stop kontak yang terdapat pada diagram pengawatan.

(Dokumentasi: Ridwan Lutfi)

- Simbol penghantar (kabel) yang digunakan dalam diagram garis tunggal.

Simbol penghantar dengan garis horizontal dengan terdapat dua garis diagonal (garis miring), jumlah kabel yang terdapat pada satu pipa. Warna merah digunakan sebagai tanda arus listrik yang mengalir bermuatan positif, sedangkan warna hitam bermuatan arus negatif (agar mempermudah pemahaman dalam diagram rangkaian instalasi listris warna hitam diganti dengan warna biru diguna untuk membedakan dengan garis denah ruangan/bangunan.

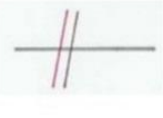

Gambar 8. Simbol penghantar (kabel) yang terdapat pada diagram garis tunggal.

(Dokumentasi: Ridwan Lutfi)

Proses dari rancangan gambar ke pemasangan/perakitan instalasi listrik adalah tahapan yang harus dipersiapkan dengan matang. Sebagaimana gambar di atas, berbagai macam bentuk simbol tersebut, digunakan untuk menentukan tata letak komponen listrik dalam suatu ruangan/bangunan. Kemudian garis/simbol yang saling tumpang tindih pada gambar rangkaian instalasi listrik menghasilkan bentuk baru.

Hal tersebut serupa dengan penciptaan karya seni grafis yang dituntut untuk berpikir terstruktur, karena dalam proses pengerjaannya dibutuhkan ketelitian dan kesabaran. Banyak aspek yang perlu diperhatikan ketika membuat karya seni grafis, seperti kelayakan ruang meliputi kebersihan dan 
alat pendukung (mesin pres, pisau cukil untuk relief print, penggores untuk intaglio) harus dipersiapkan terlebih dahulu.

\section{Transformasi Bentuk Geometris}

Penciptaan karya yang men-transformasi bentuk geometris ini merupakan wujud dari pengembangan unsur seni rupa seperti: bentuk, bidang, garis, komposisi. Melalui unsur seni rupa, penulis mengeksplorasi bentuk-bentuk geometris serta bereksperimental dengan menambahkan unsur cahaya dan gerak sehingga menjadi bentuk baru yang secara visual terlihat artistik.

Bentuk geometris pada simbol dalam instalasi listrik akan penulis transformasi ke dalam bentuk karya seni grafis. Transformasi adalah sebuah proses perubahan secara berangsur-angsur sehingga sampai pada tahap ultimate, perubahan yang dilakukan dengan cara memberi respon terhadap pengaruh unsur eksternal dan internal yang akan mengarahkan perubahan dari bentuk yang sudah dikenal sebelumnya melalui proses menggandakan secara berulang-ulang atau melipat gandakan.

Proses penciptaan karya grafis yang mengkombinasikan teknik konvensional (intaglio) dan dengan menggunakan mesin laser. Karena menurut penulis, cara kerja mesin laser sama dengan cara kerja seni grafis yang hasil cetakannya dapat dilipat gandakan. Bagi penulis menggunakan mesin laser hasil yang ingin dicapai (tingkat akurasi) sama persis dengan desain. Melalui mesin laser tidak hanya desain saja yang ditransfer, melainkan dapat juga menciptakan parit-parit (garis-garis) yang hasil, ukuran (lebar garis) dan kedalamannya sama persis sesuai desain.

Bagi penulis, mesin laser adalah alat bantu untuk mencapai suatu bentuk yang tidak dapat dilakukan secara manual. Penggunaan mesin laser sebagai proses mencetak dari file data dengan bantuan komputerisasi. Melalui penggunaan mesin laser dengan menambahkan unsur cahaya dan gerak yang disatukan dengan ukuran tertentu akan menghasilkan bentuk baru. Hal inilah yang menjadi dasar pemikiran penulis untuk bereksperimen dalam menciptakan karya seni grafis dengan mentransformasi bentuk geometris. Menurut pandangan Paul Laseau (1986), ada empat kategori transformasi: 
- Transformasi bersifat Tipologikal (geometri) bentuk geometris yang berubah dengan komponen pembentuk dan fungsi ruang yang sama.

- Transformasi bersifat gramatikal hiasan (ornamental) dilakukan dengan menggeser, memutar, mencerminkan, menjungkir balikkan, melipat dll.

- Transformasi bersifat refersal (kebalikan) pembalikan citra pada figur objek yang akan ditransformasi dimana citra objek dirubah menjadi citra sebaliknya.

- Transformasi bersifat distortion (merancukan) kebebasan perancang dalam beraktifitas.

Transformasi menurut Laseau di atas menjadi acuan penulis untuk menciptakan karya, yaitu penggabungan bentuk geometris yang didapat dari simbol dalam rangkaian instalasi listrik dengan karya seni grafis (intaglio) yang penulis ciptakan dari tahun 2013-2015 dengan bereksperimental melalui unsur gerak dan cahaya di dalam mewujudkan karya tugas akhir ini melalui transformasi bentuk geometris.

Rangsangan awal yang memotivasi untuk menciptakan karya dengan bentuk-bentuk geometris, adanya ketertarikan pada bentuknya yang mudah dikenal dan mempunyai kontur tegas dan terukur. Pengukur eksternal sama secara matematis dalam berbagai arah disebut dengan bentuk geometris.

Dengan memanfaatkan teknologi mesin laser sebagai sarana untuk mem-visualisasi gagasan artistik. Ketika penulis mengeksplorasi bentukbentuk geometris dengan komputer grafis, ide/gagasan artistik muncul tanpa disadari sehingga hal ini merupakan rangsangan untuk mengembangkannya melalui penggunaan mesin laser.

Proses berkarya menggunakan mesin laser penulis teringat dengan salah satu teknik memotong kertas. Yaitu teknik kirie. Teknik dalam seni Jepang dengan cara memotong kertas secara tradisional yang digunakan untuk membuat action figure maupun crafting. Namun seiring dengan pekembangan zaman, cara kerja tradisional memotong kertas ini, dapat digantikan dengan bantuan mesin laser. 


\section{E. Metode}

Bentuk geometris memberikan banyak kemungkinan pada pengolahannya secara teknis. Pada pelaksanaannya penulis lebih mengolah unsur rupa seperti; bentuk, bidang, garis dan komposisi. Objek visual tersebut diperoleh dari transformasi dan penyusunan bentuk-bentuk geometris, baik secara dua dimensional maupun secara tiga dimensional. Dalam hal ini objek tiga dimensional diperoleh dari penyusunan, penggabungan, dan perakitan bentuk-bentuk dua dimensional. Proses ini dimaksudkan untuk mencari kemungkinan bahwa bentuk geometris seperti segitiga, ketika disatukan akan membentuk pola tiga dimensional. Hal tersebut menjadi landasan transformasi dari dua dimensional ke tiga dimensional.

Sebelum men-transformasikannya kebentuk tiga dimensional, penulis mencoba memvisualkan terlebih dahulu dengan bantuan software komputer. Melalui pemanfaatan alat digital seperti komputer, visualisasi dari sebuah karya seni grafis dapat diprediksi/diperhitungkan. Karena pada proses pembuatan rancangan sejak awal dapat terdeteksi di layar monitor, banyak peluang untuk melakukan eksplorasi dan alternatif untuk mendapatkan kepuasan artistik. Seperti bentuk segitiga yang dihasilkan melalui proses engraving pada permukaan acrylic sheet dengan menggunakan mesin laser. Ketika bentuk segitiga digabungkan dengan hasil cetak intaglio yang berbentuk persegi, maka hasil yang didapat adalah bentuk baru. Bentuk yang secara visual terlihat artistik dengan menambahkan unsur cahaya di dalamnya.

Penggunaan mesin laser, tingkat akurasi yang dihasilkan jauh lebih tinggi. Karena melalui mesin laser parit-parit yang dihasilkan jauh lebih akurat (hasil cetakannya melalui teknologi digital). Penggunaan mesin laser sebagai proses mencetak dari file data dengan bantuan komputerisasi.

Pada proses perwujudan karya Penulis mengadopsi teknik putar dan tumpang tindih (berlapis) dari teknik cetak tinggi yang proses pewarnaannya mengunakan satu klise di atas kertas yang sama. Teknik tersebut membentuk sebuah ilusi ruang dan bentuk maupun percampuran warna akan menghasilkan ruang visual dengan sendirinya. Seperti, warna merah bertumpuk dengan warna biru menghasilkan warna ungu atau sebaliknya. Langer (2000, hal. 310) menyatakan bahwa semua karya seni merupakan sebuah ilusi, yang dalam terminologi Langer disebut imaji 
virtual. Ruang visual murni adalah sebuah ilusi, karena pengalaman sensoris kita tidak mencapai kesepakatan tentang ruang visual tersebut.

Penulis menghadirkan karya dalam tugas akhir ini dengan merespon bentuk simbol yang terdapat pada rangkaian instalasi listrik, dan bereksplorasi melalui karya-karya seni grafis yang penulis ciptakan dalam kurun waktu 2013-2015 dengan bereksperimental menggunakan unsur cahaya dan gerak, yang nantinya akan ditrasformasikan kedalam bentuk geometris melalui seni grafis.

\section{PEMBAHASAN}

\section{A. Konsep Perwujudan}

Pemilihan ruangan serta penempatan karya adalah kunci keberhasilan suatu pameran. Dalam menentukan ruangan, penulis memilih galeri Fajar Sidik yang terdapat pada gedung grafis lantai satu Fakultas seni rupa Institut seni Indonesia Yogyakarta sebagai ruang pameran Tugas Akhir penciptaan karya seni.

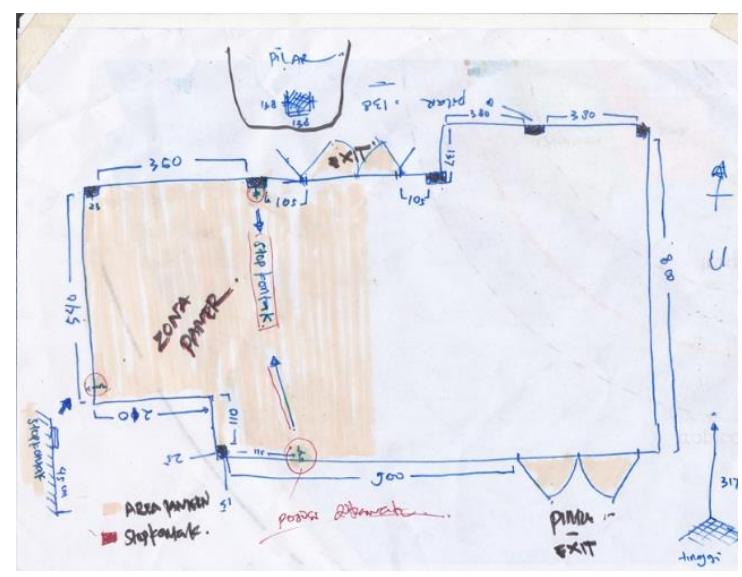

Gambar 9, Sketsa ruangan galeri yang nantinya akan digunakan. (Dokumentasi: Ridwan Lutfi, 2017)

Bagi penulis, peranan stop kontak memiliki kesan yang mendalam sebagai penghubung/penyalur arus listrik yang nantinya akan digunakan. Ruangan tersebut dipilih penulis karena bagian dindingnya terdapat tiga stop kontak. Ketika ditarik garis dari setiap stop kontak akan menghasilkan bentuk segitiga. Segitiga merupakan bentuk yang menjadi dasar dari proses berkarya penulis. Melalui pameran tersebut, penulis nantinya akan menghadirkan karya-karya yang 
menggunakan unsur cahaya dan gerak sehingga membutuhkan ruang gelap serta sumber tenaga listrik yang dibutuhkan

\section{B. Hasil Pembahasan}

Melalui pemahaman dan pengetahuan yang penulis pelajari ketika duduk dibangku SMK dalam pemanfaatan tenaga listrik. Penulis menghadirkan karya yang memanfaatkan tenaga listrik serta instalasi listrik didalamnya. Penggunaan instalasi disini bukan sekedar sebagai penghubung/penghantar, melainkan bagian dari bentuk visual yang ingin penulis hadirkan. Penggunaan cahaya dan ruangan gelap serta instalasi di dalamnya, membangun kesan dramat is terhadap ruang.

Melalui karya-karya tugas akhir ini, setiap karya adalah proses belajar yang intens. Banyak hal dapat menjadi hambatan maupun dukungan. Penulis memahami dan menyikapinya sebagai tantangan yang membangun dan dapat memperkuat karakter penulis dalam berkarya. Di dalam proses berkarya, banyak kejutan dan sensasi artistik yang penulis dapatkan. Sebagian besar justru membuka peluang pengembangan karakter visual yang penulis tekuni selama ini.

Berkarya seni merupakan proses memahami, mempelajari, menilai, menyikapi dan mempresentasikan. Semua hal yang pernah didapat akan menentukan peranan perupa dalam kehidupan berkeseniannya.

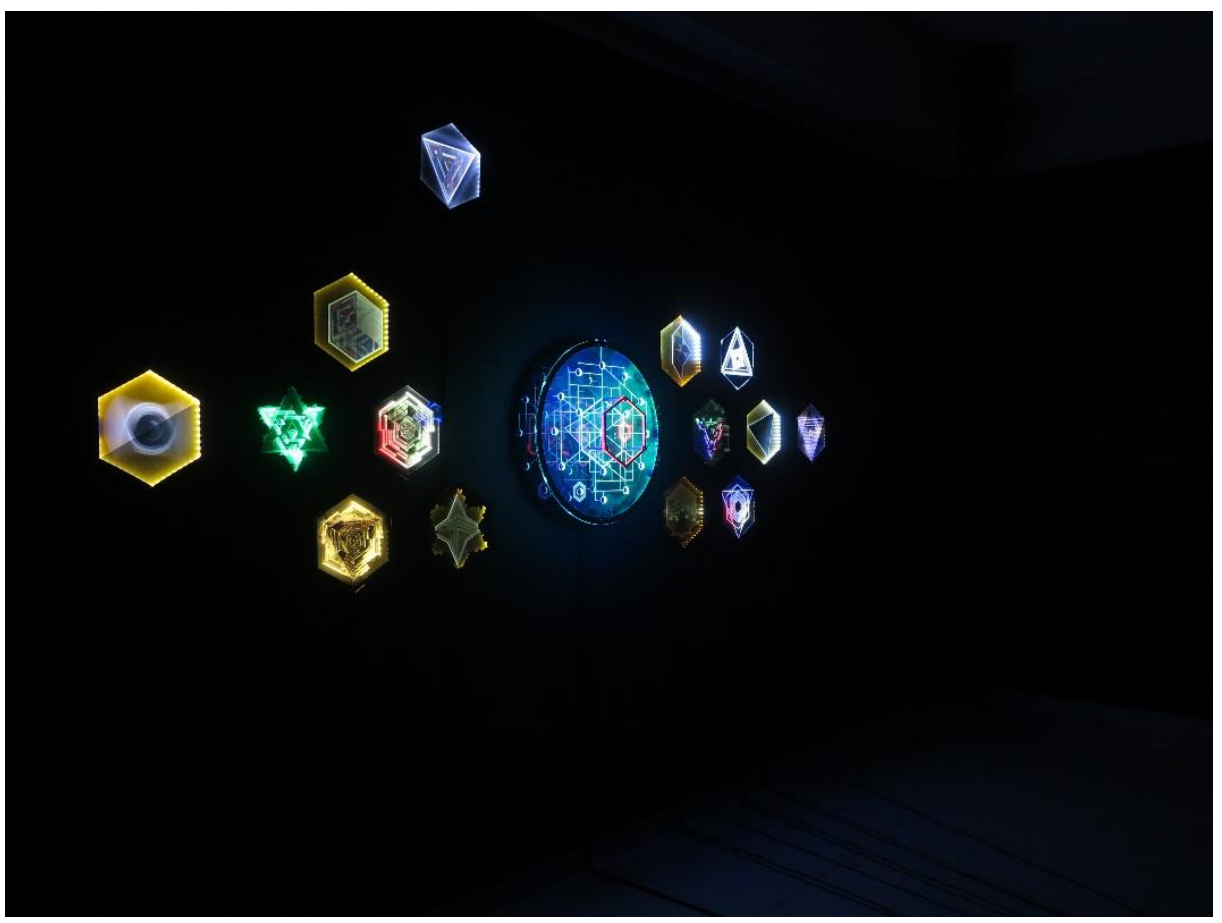




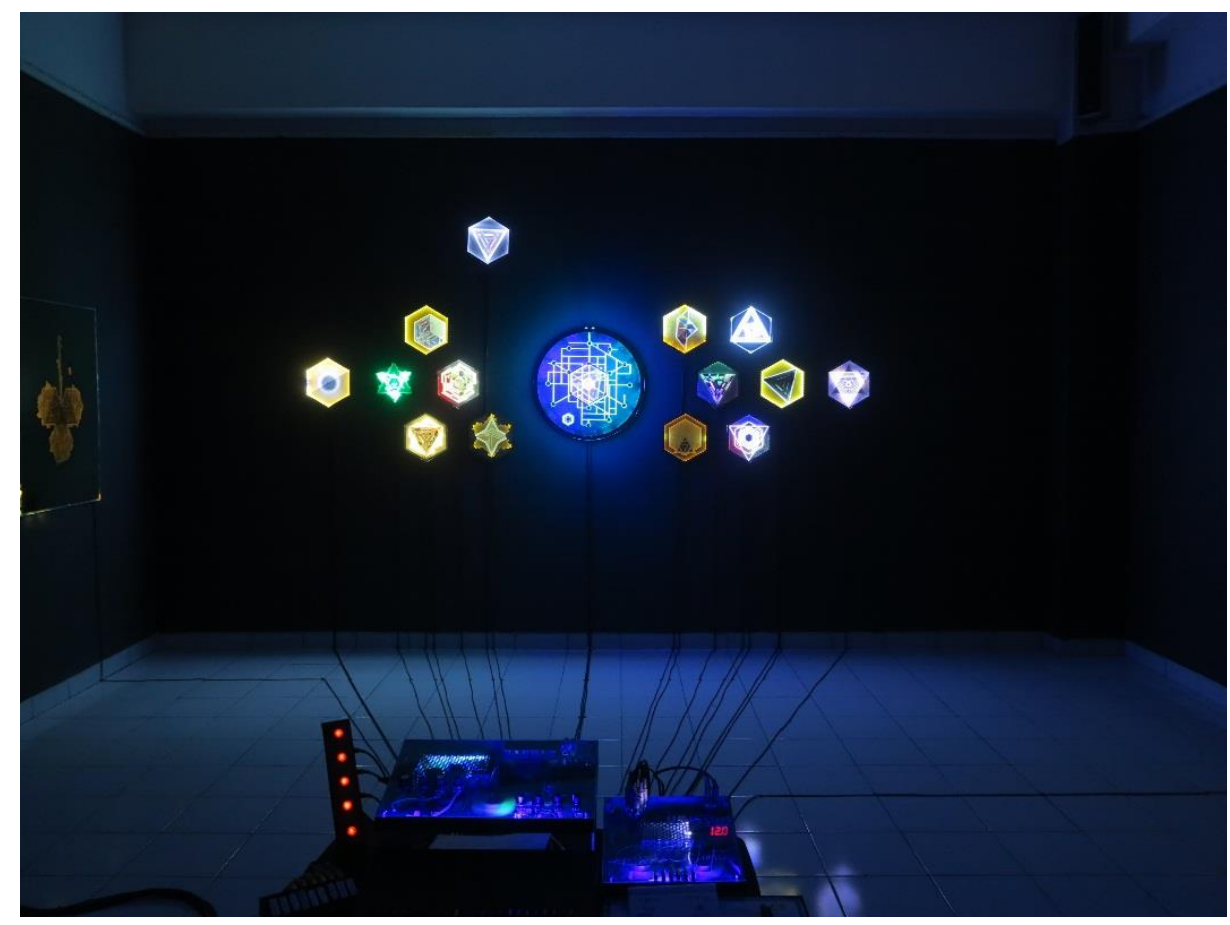

Gambar 10. "Seri Transformasi"

Etsa pada kertas, Cutting, Engraving, LED, Motor DC, Frame Acrylic, Dimensi Variabel 2017

(Foto: Ridwan Lutfi, 2017)

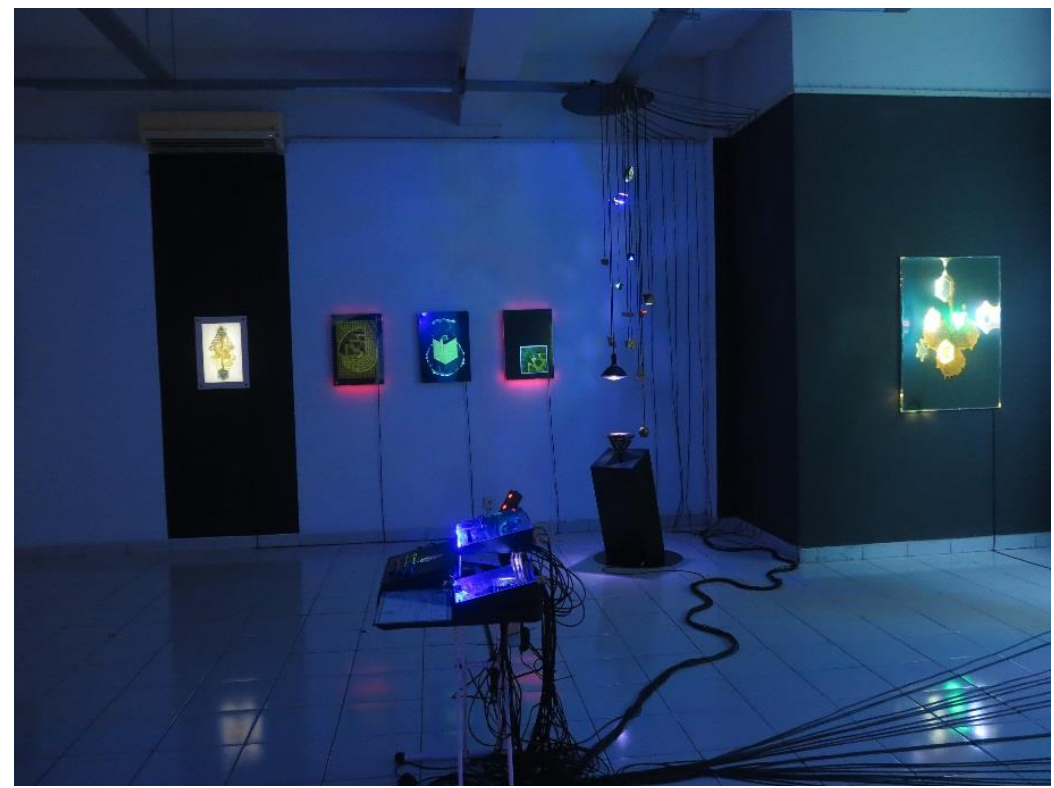

Gambar 11. Ruangan Pameran

(Foto: Ridwan Lutfi, 2017) 


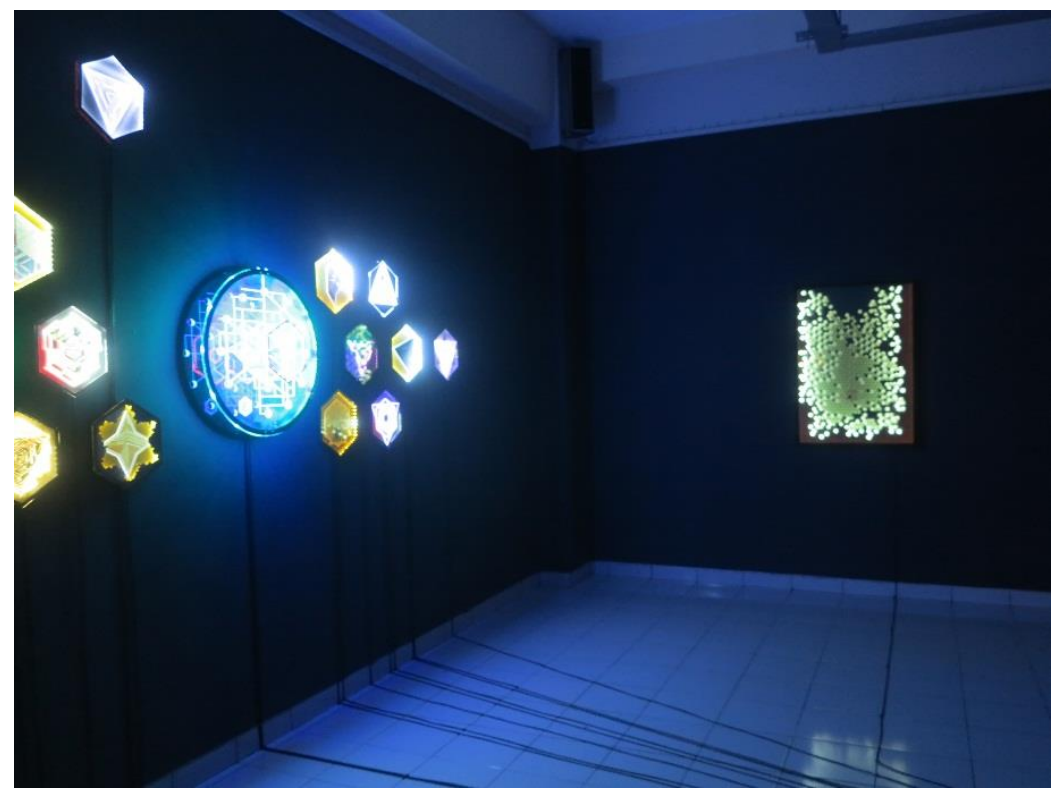

Gambar 12. Ruangan Pameran

(Foto: Ridwan Lutfi, 2017)

\section{DAFTAR PUSTAKA}

\section{Buku:}

Bates, Kenneth F. 1975. Basic Design, New York: Furk and Wagnalis.

Departemen Pendidikan Nasional. 2008. Kamus Besar Bahasa Indonesia (KBBI). Edisi ke-4. Jakarta: Gramedia Pustaka Utama.

Djiteng, Marsudi. 2011. Pembangkit Energi Listrik, Jakarta: Erlangga.

Encyclopedia American XI. 1984. New York: Grolier Inc.

Mayer, Ralph. 1975. A Dictionary of Art Term and Tecniques. New York: Apollo Edition

Rasmusen, Henry N. 1950. Art Structure, A Textbook Of Creative Design. New York, Toronto McGraw -Hill Book Company, inc: New York.

Santrock. Jonh W. 2010. Piskologi Pendidikan Edisi Kedua, Jakarta. Kencana Prenada Media Group.

Sidik, Fajar dan Prayitno, Aming. 1984. Desain Elementer. Yogyakarta: STSRI "ASRI".

Susanto, Mikke. 2012. Diksirupa, DictiArt Lab \& Djagad Art House. Yogyakarta \& Bali. 
W.A Darmaprawira, Sulasmin. 2002. Warna Teori dan Kreativitas Penggunanya. Bandung: ITB.

Zuhal. 1995. Ketenagalistrikan Indonesia, Jakarta: Ganeca Prima.

\section{Website:}

https://www.Journal of urban society's art. diakses pada tanggal 18 mei 2017, pukul 20.29 WIB

http://www.dictionary.com/browse/transform diakses pada tanggal 15 februari 2017, pukul 14.00 WIB

http://www.ar.itb.ac.id/wdp/ diakses pada tanggal 20 maret 2016, pukul $20.30 \mathrm{WIB}$ 